\title{
"When the Kalmyks saw me, they thought I was their black devil": Inverting Centres and Peripheries in Colonial Travelogues Written by East Africans
}

\author{
KATHARINA WILKENS \\ University of Leipzig, Germany
}

\begin{abstract}
Travelogues are a rich medium through which to explore observations of everyday culture and rituals, perceptions of the world order, and narrative strategies of othering. In this paper, I turn my attention to travelogues written by East Africans (coastal Swahili Muslims, diasporic Shi'i and Parsi South Asians, and Christian Ugandans) in the late nineteenth and early twentieth centuries. Although the authors come from different religious groupings, cultural-linguistic backgrounds and socio-economic milieus, they travel the same routes within East Africa and, occasionally, also to Europe or even as far as Siberia. I argue that the texts (including journals, retrospectives, and ethnographies) must be read as documents of East African cosmopolitanism. Mobility enables the authors to subvert the imperial world order by re-framing it narratively according to their own religious identity. This gives rise to reflections on humanity, equality and the beauty of knowledge, but not to the exclusion of racial and religious bigotry within and between the non-European communities in East Africa. In my analysis, I tease out narrative patterns, observational styles, and literary tropes present in the texts across religious boundaries. As all the texts were either commissioned by Europeans or edited by their translators before publication they do not document naively 'authentic' perspectives of East Africans, but reflect the complexities of communication within strict racial hierarchies. In concluding, I discuss the potential of religion to invert colonial centres and peripheries: European metropoles become places of exotic fascination while the familiar practices of co-religionists can turn the 'hinterland' into centres of learning.
\end{abstract}

KEYWORDS Religious framing, narrative, travel, East Africa, Europe, colonialism

\section{Introduction}

Travel narratives are emotional, affective affairs. It is their aim not only to transmit factual knowledge, but also to show how that knowledge is to be valued and how it should affect the readers or listeners. Written in the first person, travelogues require the authors as the 
main protagonists of the plot to position themselves between familiar and alien cultures. By bringing together a number of travelogues authored by East Africans of various religious, socio-economic and linguistic backgrounds from the turn of the twentieth century, I can show how non-Western narrators navigate the entanglements of a complex cosmopolitan society in the colonial era and predicate their own identity upon it. In the imperial context, the authors articulate independent subjectivities that certainly acknowledge (and often approve of) British and German political rule, but balance this hegemony with a sense of cultural and religious autonomy. While none of the journeys under scrutiny here were religiously motivated, it is their religion that gives all the authors their perspective on cosmopolitan mobility, global connections, colonial hierarchies and the overall perception of centres and peripheries. It is my contention that in their travelogues the authors can narratively invert existing hierarchies and centre the world order in their own milieu in opposition to the imperial world order. Religious belonging, and the truth claims behind it, open up the most important avenue for re-evaluating the existing social order according to principles of humanity, religious education and salvation.

The title-giving quote (which is discussed in more detail below) is taken from the travelogue of Silimu bin Abakari, servant of a German military officer in German East Africa, who travels with his master through Russia and into Siberia on a leisure and hunting trip (Abakari 1901b). In his journal of the expedition, he describes the beauty of orthodox churches and the piety of the people and stresses the dominance of Christianity in Russia (Abakari 1901b, 261). He is thus taken totally by surprise when he meets Muslim Tatar waiters (whom he calls 'boys' in the terminology of the British Empire) in a St. Petersburg hotel. He is even more astounded when he meets shamanic Kalmyks in Siberia and is able to use their behaviour towards him to comment obliquely on established racial hierarchies. Instead of bowing to the white men in his company, the Kalmyks bow to him, the East African black Muslim servant, because for them their own black spirit is the highest divinity (Abakari 1901b, 255, 269).

Silimu's Islamic perspective on the world he travels in cuts across national and imperial boundaries. In the same way, all the East African narrators I discuss here are enabled by their Sunni, Shi'i, Parsi and Christian frameworks to transcend the political restrictions imposed on them in the imperial order. Religious plurality is characteristic of the East African colonial contact zone. While the authors have little political power beyond that granted to them by the imperial administrations, they are very conscious of being part of a wider humanity conceived of in terms of Islam, Zoroastrianism or Christianity. Thus, imperial centres such as Berlin, London or St. Petersburg are only on the peripheries of Islamic, Biblical or Parsi worlds.

In her analysis of early modern European travelogues, Dorothea Nolde (2006) argues that authors meet the challenges of religious plurality in times of political turmoil by constructing their own religious identity through the narrative structure of travel. She refers to Protestants travelling in Catholic lands and vice versa, Western Christians meeting Orthodox Christians or Muslims and Jews in the Orient. She also observes that authors are continuously extending their repertoire of narrative styles and images to include those of their counter-religious fellow travellers. Narrativity opens up spaces of imagination in which religious differences and political oppositions can be re-ordered and revalued in ways that make sense to authors and readers alike. Pramod Nayar, who studies travelogues written by Indians detailing their visits to Britain during the height of the colonial age, concludes that "what these travelogues also demonstrate is the impossibility of reducing the Indian traveller to this identity [as colonised subject] — and this is entirely the result of a very effective set of self-fashioning modes, in 
terms of the discursive constructions of the cosmopolitan, humanitarian or aesthetic self" (Nayar 2020, 11). In the following sections, I reconstruct a number of narrative pathways followed by East African authors through the cosmopolitan milieus of the German and British colonial empires.

The choice of texts I present here highlights the religious-ethnic diversity of the region and the widely different narrative cultures each of the authors was accustomed to (Johannsen and Kirsch 2020,1-4). Despite the differences, however, I want to draw attention to the subversive quality of their texts, which is achieved through a variety of narrative strategies that cut across religious and socio-cultural backgrounds. I present these strategies in typological arrangement, generally drawing on at least two authors of different religious backgrounds under each heading. Independent of whether the inversion of centres and peripheries follows a Parsi, Sunni, Shi'i or Ugandan-Christian framework, I argue that in each case the potential of religious networks and perceptions of global religious spaces is utilized to navigate the entanglements between indigenous, expatriate and colonial co-travellers, editors, readers and listeners. Preceded by a short introduction to the texts and their context, I reconstruct three narrative pathways through the cosmopolitan world of colonial East Africa and the European hubs of expansion: The section on "Routes and Roots" refers to strategies of boundary making and crossing among independent traders; "Peoples and Places" analyses observational strategies of both ethnographic and the 'curiosity-and wonder'-type; and " 'Cannibals' and 'Noble Savages' " points to the employment of these colonialist tropes from a Parsi perspective. I then continue on to discuss further colonial and postcolonial entanglements the texts are involved in through their various translators and editors. Before concluding I discuss the potential of religion to invert colonial centres and peripheries: European metropoles become places of exotic fascination while the familiar practices of co-religionists can turn the 'hinterland' into centres of learning.

\section{East African Travelogues: Authors, Texts, and Contexts}

The corpus of travel writings I analyse here encompasses several narratives written or recounted in Kiswahili, Luganda and Gujarati from the turn of twentieth century variously translated, edited and published by German, British, American, Ugandan and Kenyan scholars over the space of a century. Before introducing the texts, I will give a quick overview of the political situation and the travel infrastructure at the time.

East Africa was divided into German East Africa (later Tanganyika, now Tanzania), British East Africa (now Kenya) and the British Protectorate of Uganda. The island of Zanzibar, now a part of Tanzania, then belonged to British East Africa. Local commerce and administration, however, continued to be structured mainly through imperial Omani rule based in Zanzibar and operating under British protection. Society in the coastal cities of East Africa was dominated by Swahili traders with Yemeni, Omani and Arab settlers and South Asian entrepreneurs living among them. Kiswahili was the most widespread language, though Arab loanwords, Arabic script and a general cultural penchant for an Arabic lifestyle (Kiswahili: ustaarabu) characterised the era.

In British East Africa and the British Protectorate of Uganda, colonial administration was closely linked to India, including its currency, trading patterns and racial policies. A large number of Indian government employees, engineers and traders emigrated from Goa, Gujarat and Punjab to Zanzibar, Mombasa and Kampala (Mazrui 2017). Not least due to strictly en- 
forced racial separation, South Asians generally did not mix with the local population, and they upheld their internal religious divisions and jati structures. Catholics, Hindus, Jains, Sunni and Shia Muslims (Khoja Ismailis, Bohras and many others), Sikhs and Parsis were among the migrants, all of whom established their own communities and places of worship.

Long-distance caravan trade on the mainland was conducted mostly by Swahili-Arab traders out of the coastal cities, the most important of which was Bagamoyo in German East Africa. Trade routes were established as far west as the Zambezi and the entire Great Lakes Region, including eastern Congo. Shipping routes included regular traffic to the Arab peninsula, Persia and India. In an effort to circumvent the mainland caravan routes which all lay on German territory, the British initiated the construction of a railway line linking the coastal city of Mombasa with Port Florence (today Kisumu) on the Kenyan side of Lake Victoria. Lake Victoria was then crossed by ship with Entebbe as the port terminal. A last stretch of road led travellers into Kampala. As midway point, the city of Nairobi was founded as a workers' camp in 1896.

Trading caravans were organised by experienced caravan leaders and supervisors of the porters (wanyampara) based in Zanzibar or Bagamoyo. They were employed by Swahili, Arab or Indian traders who financed the goods (cloths, beads, guns, etc.) to be bartered against ivory and slaves. These were the same caravan leaders who accompanied Europeans on their expeditions for exploration, hunting and war. They were responsible in turn for hiring porters, clothing them, feeding them and paying them a small remuneration. Total travel time had to be reckoned in weeks, or more often than not, in months. When the railway opened in 1903 it took two days to reach Nairobi and another two to reach the shore of Lake Victoria. At the same time, telegraph communication was being installed throughout both colonies.

With the opening of the Suez Canal, fast maritime routes to Europe were serviced out of Zanzibar and Mombasa by German, British and various other shipping companies with weekly timetables. Other ships frequented Arab, Persian and Indian harbours, while some went south towards Mozambique and South Africa. Indian and Arab traders had plied these same routes for centuries with sailing ships called dhows.

The corpus of text I will present now spans all of these religious-ethnic groups and methods of travel just described. Five authors provide texts in Kiswahili of twenty to fifty pages' length. The texts were commissioned, written down from dictation or transcribed from Arabic script, translated and published bilingually by the German language instructors Karl Büttner (1894) and Carl Velten (1901a, 1901b). ${ }^{1}$ Amur bin Nasur was a Kiswahili language instructor from Zanzibar who spent several years in Berlin. His short autobiography, travelogue and ethnographies on Berlin and Zanzibar were published by Büttner (Nasur 1894). The ivory trader Selemani bin Mwenye Chande provided Velten with an account of his adventures en route to Lake Tanganyika and into the Congo (Tshande 1901), as did Abdalla bin Rashid, a leader of the porters for a German expedition (Rashid 1901). Two travelogues and ethnographies of neighbouring coastal peoples are provided by Mtoro bin Mwinyi Bakari, the successor of Amur in Berlin (Bakari 1901a, 1901b). Silimu bin Abakari recounts his travels in three parts: he accompanied his German master, Theodor Bumiller, on an East African expedition, on a voyage by sea and rail from Zanzibar to Berlin, and on the above-mentioned hunting trip in

1 My English translations of the Swahili texts are from the original Swahili and not from the German translations, unless otherwise noted. 
Russia and Siberia (Abakari 1901a, 1901b, 1901c). ${ }^{2}$ Linguist Thomas Geider has summarised the historical contexts and some linguistic features of these texts (Geider 1992).

Two sixty- to seventy-page accounts by British East African residents of Indian descent include the journal of Ebrahimji Noorbhai Adamji ([1905] 1997), a young Bohra merchant (Gujarati Shi'i Muslim) from Mombasa who travelled on the newly built railway in order to help the trading enterprise of his brothers; and the account by Sorabji Darookhanawala ([1905] 1997), a wealthy Zanzibari civil engineer who travelled for his own pleasure and edification on the same railway. Darookhanawala's book was originally published by himself through a printer in Bombay, but the only version of his text that is available today is the translation overseen by Cynthia Salvadori (1997), and published together with the journal of Adamji. Gaurav Desai (2013, 85-111), a scholar of English and South Asian literature, provides a narrative analysis of these texts-to my knowledge the only one that has been done. Historian Nile Green (2012) discusses in detail an anonymous settler's manual written by an Urdu engineer in the context of railway construction in British East Africa, and compares some aspects of it to the travelogues presented by Salvadori.

Ham Mukasa presents a book length report of a journey to Britain to attend the coronation of King Edward VII (Mukasa [1904] 1998). Ham Mukasa was a chieftain's son who had been raised as a page at the royal court and who at the time of travel was acting as secretary to the Bugandan prime minister and regent, Sir Apolo Kagwa, who represented the child king of Buganda, Daudi Chwa. Both Apolo Kagwa and Ham Mukasa were Anglican converts and both had written extensively in Luganda on Bugandan history and biblical theology (Kahyana 2018; Behrend 1998). They were formally invited to attend the coronation ceremony in the capital of the empire along with many other representatives from the realm. Ham Mukasa's journal was written in Luganda as a cooperative project between himself and Apolo Kagwa, but it was only published in English. The translation and publication of the book in Britain was prompted and financed by their fellow traveller and Anglican missionary in Uganda, Ernest Millar. ${ }^{3}$

The analysis of travel writing, in general, is a research field in literary studies (Youngs 2013). But the potential of narrativity as a source for cultural history (Nolde 2006) and cultural anthropology (Pratt 1992; Clifford 1997) has been readily recognised. Questions of motivation for travel, dependencies between narrators and co-travellers (masters, hosts, servants, colleagues), intertextual references, or narrative styles of introspection, wonder and description of space-time have to be approached differently in travelogues not written by the prototypical Euro-American, white, male travelling adventurer. In the framework of postcolonial studies, travelogues written by non-Western authors reversing the traveller-travellee framework of exoticism and critique ${ }^{4}$ are studied now by Western and non-Western scholars

$2 \quad$ Note must be made of changing conventions in the transliteration of given names. Velten and Büttner use the early German conventions I give in the bibliography, but in the body of my argument I follow the current conventions of Kiswahili spelling and naming. This means that Selim bin Abakari will be called Silimu bin Abakari in this article, or Silimu for short (Abakari 2015); Sleman bin Mwenyi Tshande becomes Selemani bin Mwenye Chande, or Chande for short (Mustafa 2015); and Mtoro bin Mwenyi Bakari becomes Mtoro bin Mwinyi Bakari or Mtoro Bakari for short (Wimmelbücker 2008, 4). Salvadori (see below) points to a similar problem with the suffix -ji/-jee attached to a name. Following her transliteration, I keep the -ji suffix.

3 The original manuscripts of the Ugandan and Indian texts are not readily available. I have only been able to consult the published English translations. Thus, the linguistic analysis of these texts cannot be as close as for the Swahili texts.

4 Travelogues generally include depictions of those people encountered along the way and at the destination of their travels. Recent studies of Western travelogues show that a typical literary device to enhance the 
alike (Alam and Subrahmanyam 2007; Nayar 2020; Pettinger and Youngs 2020; Idrissi Alami 2013; Newman 2017; Khair and Ghosh 2006; Green 2014). The literary voices of dependent travellers, servants, pathfinders and others are also gaining more and more attention (Forsdick, Walchester, and Kinsley 2019; Walchester 2020; Mackenthun, Nicolas, and Wodianka 2017; Smethurst and Kuehn 2015).

The identity of the narrator is of greatest importance to the construction of a travelogue. On the one hand, the plotline follows the enrichment and growth of the narrator's character through new experiences. On the other hand, it must simultaneously stabilise core values of the culture of origin in order to prevent the narrator from 'going native'. This double aim is achieved through descriptions of proximity and distance, wonder and ridicule, empathy and disdain, centre and periphery. Typical tropes of travelogues thus always include comments on food and clothing, hygiene, comportment and architecture. Geographical differences are referenced through remarks on temperature, humidity, vegetation and specific landscape features. As travellers are heavily dependent on hospitality wherever they go, the treatment of foreigners in strange places, including meals and sleeping arrangements, is one of the most prominent tropes of all. In this respect, the East African authors presented here are not different from Western authors.

However, in contrast to the highly emotional and sensitive accounts of European travellers in the Romantic and Victorian periods, East African authors focus much less on interiority or self-awareness as a stylistic instrument. Also, the authors make little reference either to history or nature in concrete detail or as abstract categories. They were simply seldomly motivated by a wish for educating themselves or their readers - this being mentioned explicitly only by Mtoro Bakari and Darookhanawala. Rather, travel meant work, either for trade or in servitude, which determined the focus of the narratives on pragmatic aspects of travelling. As such they are very similar to the accounts of late eighteenth and early nineteenth century travelling servants analysed by Kathryn Walchester (2020), as well as pre-Victorian Western (Nolde 2006), North African (Idrissi Alami 2013) or Indo-Persianate (Alam and Subrahmanyam 2007) genres of travel writing.

\section{Routes and Roots: Religious Boundaries in Commercial Travel}

Selemani bin Mwenye Chande, an independent Muslim ivory trader who had begun his career as leader of the porters in a caravan, provides a very detailed account of his longest trading expedition in the year 1891, starting in Bagamoyo and traversing the interior, crossing Lake Tanganyika into Congolese territory and returning south of the lake to Bagamoyo. The style of the texts is one of oral narration. Highly repetitive phrases, for example, include "then we ate our evening meal, and then we slept" or "then we woke up and had our morning meal and then we went to (this village or that attraction)." Meals and rest at night structure the space-time of the travel narratives between which extraordinary events unfold. This text is of historical interest as it gives insights into things like bargaining patterns in respect of hongo, the fees charged by village chiefs for passing caravans (Pesek 2006); the barter of cloth and ivory with exact prices and amounts (Alpers 1975); the names of villages and chiefs and their

perceived power and knowledge of the author-traveller the travellee are characterised as quaint, exotic and generally not particularly purpose-driven. Postcolonial critics point out that this literary figuration of the travellees diverges markedly from the historical agency they did have, both within their societies in general as well with a view to controlling the actual travel arrangements of the traveller-author (Smethurst 2019). 
political alliances along the way; and personal perceptions of the travelling infrastructure, sleeping arrangements, provisioning, and customs of welcoming strangers. ${ }^{5}$

Chande refers to himself in the text as a "mwungwana," a term Velten translates as "man from the coast," but which also implies a certain urban Arab refinement and Muslim identity within Swahili coastal society (Middleton 1992). This term is often used in opposition to the term "mshenzi," a man from the bush, or pagan villages, often implying a person who is not trustworthy because he does not have the habits of "coastal civilisation." These two appellations are used throughout the narrative, thus clearly distinguishing the Muslim and coastal identity of Chande and the other caravan leaders from the village chiefs he encounters during his travel. Another mark of distinction is the caravan leaders' observance of the prohibition of intoxicating drinks: Chande consistently refuses to drink locally brewed beer (pombe) when it is offered to him, even when he risks being undiplomatic.

The belief in ancestral interventions in the lives of humans, however, is shared by Chande and the people of the "hinterland," as his adventures in the land of the Fipa show. The caravan came to a village inhabited by Fipa who regularly provided small boats (mtumbwi) for travellers on Lake Tanganyika. The first point they arrived at was "the place of Wampembe, that is an ancestor spirit of the Fipa; they come here to make sacrifices to them at all times (kutambikia)" (Tshande 1901, 20). It is the same place the boats were kept and where the caravan leaders negotiated passage with the chief. The next day, they boarded the boats and started rowing, but were soon caught up in a heavy storm $(1901,23)$. The Fipa rowers suggested they should row quickly to a nearby island to make sacrifices to the ancestor Wampembe at his shrine (mzimu). They offered a selection of coloured cloths from the merchandise belonging to Chande, asked Wampembe for safety on their journey ("utupe salama ya safari"), and within minutes the winds died down.

From this short but highly emotional passage we learn that Chande has no qualms about asking ancestor spirits for help during a crisis. His mwungwana identity does not prejudice him against offering sacrifices to Fipa spirits, at least not in such a dire moment as this. However distrustful he is of shenzi habits in general, and however difficult communication via interpreters can be, this is a moment of shared religious culture. There are no accusations of barbarism or pagan idolatry. This attitude corresponds to that of another mwungwana, Mtoro bin Mwinyi Bakari, who describes instances of spirit possession and ancestor sacrifices as part of Swahili Muslim coastal culture (Velten and Mwenyi Bakari 1903a). But Mtoro Bakari does insist, however, that no spirit ritual be performed on him, as that would collide with his personal convictions concerning his Muslim identity (Velten and Mwenyi Bakari 1903a, 147-48; see also Wimmelbücker 2008, 11). Thus, there is a certain latitude with respect to how far such interactions between mwungwana and non-mwungwana identities should go.

Just a few years later, in 1903, the young Bohra (Shiite) merchant Ebrahimji Adamji cuts short a porter caravan in Kenya by taking the train. A Baluchi ivory trader owed Adamji's family's company, which was based in the coastal city of Mombasa, a substantial number of elephant tusks. But instead of delivering them to the coast, he seemed to be selling them to other merchants further inland. So Adamji decided to intercept him in Port Florence (Kisumu) on Lake Victoria at the end of the newly opened railway line. Adamji kept a journal of this

$5 \quad$ Rashid (1901), a high-ranking caravan leader in the expedition of Graf von Götzen which traversed the continent from the Indian Ocean to the Atlantic Ocean, structures his entire narrative around the availability of provisions for the porters under his command, again providing exact details of prices, types of food and amounts acquired. His account closes with a devastatingly bald summary of five hundred lives lost during the expedition. 
journey, as well as of three subsequent journeys by rail and on foot in pursuit of ivory, to the exclusion of caravan middlemen. In a style similar to that of Chande's account, he lists names of trading partners, prices and availability of goods in minute detail. ${ }^{6}$

His Shiite religious identity is expressed by formulaic gratitude such as the mention of 'God and the Holy Five,' i.e., the Prophet Mohammed and his family. To boost his motivation for travelling and in occasional moments of loneliness and desperation, Adamji reflects on questions of life and death, and the finiteness of men's endeavours: "I had nobody of my own in this desolate place. I only had God and my faith in the Holy Five. [...] A man dies but once and if God had that in his mind then I would die, but not go back. The one whom God cares for, nothing can harm. Thus I encouraged myself and started my journey again" (Adamji [1905] 1997, 53). These flashes of sentimental style in the otherwise prosaic journal are reminiscent of Persianate styles of travel writing (rihla), though no explicit references to particular texts are made.

Adamji's strictly chronological account is structured by references to sleeping exhaustedly at night, breakfasting before starting the affairs of the day, with occasional mentions of possibilities to bathe and wash clothes. The time of the day is measured according to two systems available to Adamji as a Muslim. Social events, tea drinking, talking and eating are given by Adamji in accordance with the times of the Islamic prayers, which he performs assiduously. A very notable characteristic of the text, however, is the frequent mention of exact times in hours and minutes following European conventions. Timekeeping by the clock was probably something Adamji had learned in the missionary school he had attended and it was, of course, of paramount importance for journeys dominated by train timetables. Timekeeping by the clock as a new and modern cultural technique thus went hand in hand with travel by train, and is here a prominent element structuring narrative time.

Wherever Adamji stops on his travels, he finds shelter with other Bohras or Khojas, that is other Shia Muslims. He hardly ever converses with members of other castes or communities among his fellow South Asians, and only very rarely with Africans or Europeans. But travelling through the Kenyan highlands towards Nairobi, Adamji finds himself so cold one night that he has to accept a "very smelly quilt" from a Lohana Hindu man (Adamji [1905] 1997, 53, 21 22). This little episode demonstrates the deeply embodied disgust generated by religious and caste distinctions in Indian society at this particular point in time. But the dire circumstances force Adamji to overcome his distaste: "although I was really uncomfortable I managed to get through the night. I was so grateful to him" ([1905] 1997, 22). Thus, in the narratives of both Chande and Adamji, trade partnerships and accommodation are framed completely in terms of cultural and religious identity (Bohra vs. non-Bohra, Muslim mwungwana vs. heathen mshenzi), yet on the road a spirit of helpfulness arises that allows the travellers to transgress certain boundaries and create a community of fellow sufferers.

This easiness of cross-religious support, however, is not given between Silimu bin Abakari, a Sunni Muslim, and his German master. Silimu was Comorian by birth, but had moved to Zanzibar in search of work (Abakari 2015, 109-15; Diebold 2021). First finding employment in the German troops (the so-called 'Wissmann Truppe') engaged in putting down the Arab revolt led by Bushiri bin Salim in 1888/89, he was recommended to Theodor Bumiller, doctor and adjutant to Hermann von Wissmann. ${ }^{7}$ In 1891, Silimu accompanied Bumiller as personal

6 For a very detailed account of South Asian families and businesses in Kenya and Tanzania in the nineteenth and twentieth centuries, see Salvadori and Fedders (1989).

7 In German postcolonial discourse, Hermann von Wissmann is mostly remembered for the atrocities committed against the local population during the German-Arab war. His statue in Hamburg was removed 
valet on Wissmann's expedition, the goal of which was to transport a steamship to Lake Nyasa. The steamer was delivered from Germany disassembled, shipped up the Zambezi and Shire Rivers and then carried by porters to Lake Nyasa. Wissmann scouted the areas north of the lake (Kondeland), which are described in lively detail by Silimu, fought a local rebellion also witnessed by Silimu and finally returned to Dar es Salaam.

Strict hierarchies in provisioning become apparent in a small story told by Silimu. On the journey, Silimu and other Muslim servants wished to light a candle at night in order to read together from the Quran. They did so without thinking, but were found out and accused of wilful wastage by Wissmann (Abakari 1901a, 57). Silimu gives the story a conciliatory twist by saying that his own master Bumiller punished the servants less severely than Wissmann had actually ordered. But the feeling of being discriminated against, both racially ("the candles were for use by White men only") and because of their religion (reading in the Quran being classified as wasteful), is very strong and precludes any feeling of solidarity between the leaders and their servants.

Travelling with caravans for purposes of trade or as European expeditions was embedded in complex social networks and hierarchies linking the coastal suppliers and the trading posts en route. Porters and personal servants such as Silimu had to comply to the caravan leadership under the threat of corporal punishment, in his case especially embittered by a Christian prohibition of Islamic ritual. Among traders and caravan leaders of equal standing, as in the cases of Chande and Adamji, a sense of trust is the foundation of all long-distance business relationships. This trust centres on extended family networks associated with closely defined religious affiliations. But their narratives also include moments in which they receive spiritual and material assistance from outside their own perceived sphere of civilisation. Though these short narrative episodes show a certain openness and thankfulness towards Others, they also serve to highlight the deep-rooted implicitness of their primary Sunni, mwungwana and Shi'i Bohra identities.

\section{People and Places: Observing Alien Cultures and Religious Curiosities}

In travel accounts, detailed descriptions of geography, fauna and flora as well as the customs of the people can serve several purposes, often also intertwined: providing new information for educated readers and as affective projection screen for the hierarchisation of knowledge between imperial centres and peripheries, often expressed as 'curiosity' and 'wonder'. The former type of travelogue often belongs to the 'customs-and-traditions' genre which figures largely in the foundational years of the academic disciplines of anthropology and folkloristics. It was driven forward by comparativists such as James George Frazer in Cambridge-who, incidentally, received Ham Mukasa and Apolo Kagwa one afternoon for coffee during their tour of Britain, presumably asking them about their work on Ugandan sacred kingship (Mukasa [1904] 1998, 116; see also Naithani 2010, 33-35). As employees of the Seminar for Oriental Languages at the University of Berlin, Amur bin Nasur and Mtoro bin Mwinyi Bakari were actively commissioned to produce descriptive texts in the ethnographic-folkloristic genre un-

from public view as early as 1968. In the texts by Silimu German colonial politics and military tactics are occasionally mentioned - as during the voyage to Lake Nyasa-but never commented upon morally or politically. His attachment to Theodor Bumiller, however, seems to have been quite genuine and friendly (Abakari 2015, 112-13). 
der the guidance of the linguists Büttner and Velten. ${ }^{8}$ In the following, I will first discuss the ethnographies of Mtoro Bakari and Amur bin Nasur before comparing them to the affective style of observational 'curiosity and wonder' passages contained in the journals of Ham Mukasa and also, again, of Amur bin Nasur.

Amur bin Nasur's (1894) text brings together three literary genres with strong observational accuracy. After the formulaic praise of Allah marking his text as one written by a well-educated Sunni Muslim, he begins the narrative with an autobiography giving details of his parents, his extended family, his education and his early marriage. He then switches to the genre of a journal, providing lively accounts of his journey by ship and train from Zanzibar to Berlin, via Aden, Naples, Amsterdam and Hamburg. He continues with a description of his first days and weeks in Berlin as a language tutor, during which he takes up residence in a flat. He is accompanied by his student and friend Carl Velten (who later goes on to collect the other Swahili narratives discussed here) to a variety of touristic and cultural entertainment in the city, including a large military parade. In the third part, he closes his account with two mirrored ethnographic texts on housing, economy and customs in Berlin and in Zanzibar.

The ethnographic section of Amur's text was intended by his mentor Carl Büttner for colonial officials being trained for working abroad. The text served as both a linguistic exercise and an introduction to the customs of the East African colony. In the description of Zanzibar, Amur, a well-educated Arab-Swahili Muslim, expresses clear disdain for village sorcery (uchawi) - typical of folk studies in Europe at the time. He describes the housing situation in the city and the produce in the markets, and then dedicates several pages to the different types of sorcery practised by various local and immigrant peoples living on the island. He closes with details of Arab hospitality, as opposed to the lesser hospitality of the Swahili or Comorians.

The ethnographic genre is formally adopted in the texts by the coastal Swahili Muslim Mtoro bin Mwinyi Bakari. His contributions to Velten's collection of travel accounts ostensibly straddle the boundary between travelogue and ethnography. He wrote a separate book-length description of the Customs of the Swahili (Desturi za Wasuaheli), translated and published by Carl Velten (Velten and Mwenyi Bakari 1903a, 1903b). Like those of Amur bin Nasur, whom he followed as language tutor in Berlin, his accounts were written by himself in the Arabic script of Kiswahili and not dictated to Velten as were the other accounts in that collection. The linguistic style thus includes formulaic praises of God typical of any Muslim written text of the time. The accounts are more self-reflexive than the oral ones and careful composition is visible in the chapter divisions. Mtoro Bakari begins his texts by stating his wish for learning as motivation for travelling in areas near his home region, provides glimpses into his inner life and distinguishes clearly between personal experiences during the journey and ethnographic descriptions of the people he visited. The latter include aspects of traditional law, kinship taboos, birth, puberty, marriage and burial rituals, information about food and clothing, agricultural work and other crafts, traditional medicine, sorcery and ancestor veneration. These categories are akin to any 'customs and traditions'-type folkloristic ethnography of the time written by Europeans. In contrast to Amur, however, he is not critical of traditional religion, because he has other motives for his identity politics. Being of multiple descent himself, Mtoro Bakari describes people connected with his own extended family (even though they

$8 \quad$ An almost identical collection of prose narratives, including biographical texts and travelogues written in the Hausa language of Northern Nigeria was produced by Friedrich Schön (1885). The travelogue dictated to Schön in 1856 by Heinrich Barth's servant, Dorugu, was reproduced together with the autobiography of Maimana, a Hausa chief, by Kirk-Greene and Newman (1971). 
speak other languages), the Zaramo, the Udoe, the Uzigua (1901a, 1901b), and the Swahili (Velten and Mwenyi Bakari 1903a, 1903b), without applying the stereotypes of coastal ethnic hierarchisation. Amur, on the other hand, uses the sorcery stereotypes to reinforce the religious-ethnic distinction so typical of the coastal discourse on civilisation (ustaarabu, lit. Arabness).

The book length account of Ham Mukasa's travels through Britain is not ostensibly an ethnography, but it is nonetheless characterised by a strong inclination to observe the people, customs and technology of the places visited in England and Scotland. Ham Mukasa offers ample detail of culinary and vestimentary customs and curiosities, and especially British industrial advancement. The alignment of Ham Mukasa and Apolo Kagwa with British Anglicanism and British culture is very apparent in the narrative, and this attitude was heavily criticised by later generations fighting for the independence of Uganda. But reading the text closely, it is clear that Ham Mukasa's express intention of learning from the British follows from his wish to develop a new type of civilisation for his home country (Behrend 1998; Lo Liyong 1975):

See how hard it is to describe all the wonders of the English! [...] their cleverness and industry and inventive power year by year increase more and more as time goes on; but industry is not their's alone, for in all countries every industrious man will not fail to find what he searches for. (Mukasa [1904] 1998, 199, see also 204 and passim)

It is this intention of learning that initially motivated his journal writing. I argue that underneath his constant obsequiousness, a genuine interest in the things he saw motivated Ham Mukasa's observations. For example, he is happy to be able to explain to his readers in Buganda the things he learnt about the English and about Christianity on his travels. At an agricultural show in Carlisle he

saw there how they shear sheep; when they are shearing it, the sheep does not move till all the hair is cut off; and so we understood what we had heard in the prophecy about our Lord: 'He was brought as a lamb to the slaughter, and as a sheep before her shearers is dumb, so he opened not His mouth'; for we saw it being done. They shear the sheep every year, because the sheep are the bark-cloth trees of the English, which they beat out, and their wool makes the clothing that they all wear, as cotton clothing is not much worn. (Mukasa [1904] 1998, 119)

His attention to detail, which he expresses in a mix of English technicalities and comparisons to Ugandan features of culture, landscape and technology, reveals the attitude of a committed community leader looking for the best of both worlds.

The text documents every day of the entire period from May to September 1902, mentioning every shop they went to, every person they met and every factory, school or business they visited, in a style Pramod Nayar (2020) characterises as the "enumerative" and "engineered picturesque." Nayar contrasts this manner of describing technological landscapes in Indian accounts of travel to Europe with descriptions of natural beauty or the picturesque in European travelogues (Kinsley 2019). Ham Mukasa is particularly fascinated by numerical details and measurements. He gives times with a precision of minutes; he lists numbers of workers in every factory and provides the length and breadth of every machine or the revolutions per minute of engines. The descriptive aspect of the account is thus stylistically very prominent. 
Ham Mukasa also repeatedly mentions that he and Apolo Kagwa collected specimens of raw and finished materials from all the factories they visited in order to show them to their countrymen at home. By contrast, he notices the collections of African weaponry, cloths, animal hides and other materials displayed in the houses of the colonial officials and missionary anthropologists they knew from home such as Henry Morton Stanley, Henry Johnson and John Roscoe.

The journal section of Amur bin Nasur's account of Berlin is highly stylised, in a manner centring around the wonder he feels in observing the strange things happening in circuses, theatres, museums, zoos and pubs. Velten invites Amur on a number of daily outings and each day Amur begins and closes with formulaic sentences: "And on another day he said to me: and today, let's go and see another custom (khabari). [...] I was very much astounded by these wonders and these customs. And at the end [hatta khatima] we left and we went home. Bassi" (Nasur 1894, 162 and passim). On occasion he calls upon God, the Lord of the World, to witness these wonders. In verbalising the emotions aroused by strange things witnessed in foreign parts, travellers must translate the wonders seen abroad into terms familiar to their readers. 'Wonder' is a key element in European and Persianate travel writing. It conveys the strangeness of foreign customs with approval and a certain amount of distancing at the same time. Not all travelogues make use of the stylistic tool of 'wonder' in the same way. Amur bin Nasur is overwhelmed and slightly taken aback by theatres, circuses, museums, pubs and zoos, while Ham Mukasa wholeheartedly admires the intricacies of factory production (Behrend 1998).

The ethnographic genre of observation employed by Amur bin Nasur and Mtoro Bakari closely follows German conventions of the time, ordering information according to subject matter (religion, law, housing, agriculture, food and drink, and so forth). Ham Mukasa keeps to the diary genre of observational writing, but includes much information on clothing, technology, transport and religion nonetheless. In comparing the three authors, it is important to note that Mtoro Bakari describes his own people and his familiar neighbours for a German readership as does Amur bin Nasur when writing of Zanzibar. In their journals, however, Amur bin Nasur and Ham Mukasa are trying to find words for the 'wonders' of unfamiliar Europe. Below I will discuss the effect such inverse ethnography had on the editors and the readers of the time. The necessity to find locally meaningful expressions for foreign rituals, objects and stories is most pronounced in Ham Mukasa's text, who wants to educate his people at home. The genre of 'curiosity and wonder' more closely resembles oral storytelling in East Africa independent of religion or ethnicity, often accompanied by nonverbal interjections of astonishment. Ham Mukasa, for example, mentions expressly that he recounted his travels to his fellows Ugandans orally. The ethnographic genre owes its style to European academic conventions, but leaves room for inclusions and exclusions as demonstrated by the differences between Mtoro Bakari's and Amur bin Nasur's valuation of traditional religious practices vis-à-vis their own understanding of Islamic orthodoxy.

\section{'Cannibals' and 'Noble Savages': Literary Tropes from a Parsi Perspective}

The late nineteenth century and early twentieth century marked the beginning of touristic leisure travel on a global scale. The faster and more comfortable steamers became, and especially the longer the railway network became, the more travellers were enticed away from 
home for no other purpose than curiosity, education and adventure. The Uganda Railway attracted big game hunters from the beginning and by 1911 full-service tourist packages were firmly established, as demonstrated by the railway's travel brochure (Uganda Railway 1911). Thus, quite a few US-American and European accounts of trips on the Uganda Railway were written and well received by broad audiences. The Man-Eating Lions of Tsavo, which had lethally attacked the railway workers and which were finally shot by Patterson as described in his widely read travelogue and adventure story published in 1907, added to the feeling of romantic wilderness advertised by travel agents. The Uganda Railway, however, was not a uniquely 'White' enterprise. Rather, it was considered by many South Asians in East Africa to be uniquely their project, since many engineers and most manual labourers had come from the Indian subcontinent (Green 2012; Darookhanawala [1905] 1997). In the following section I present a Parsi tourist adopting the Victorian genre of leisure travelogue, but from a uniquely Zoroastrian perspective.

Sorabji Darookhanawala, a well-established Zanzibari engineer and a Parsi, gives pride in the railway construction as one of his major motives for embarking on his upcountry journey ([1905] 1997, 163). The other motives are compounded of curiosity, admiration for the beauty of the land, and the wish to pave the way for new settlers and tradespeople along the railway line: "I only want to stress that those who have the God-given energy should not lose the opportunity and enjoyment of exploring such a land!" ([1905] 1997, 167, see also 117, 119). It is especially for tradespeople and other leisure travellers that he writes the book as a guide, providing information on land quality, trading networks and prices along the way.

The Parsi community adopted British education and a generally British lifestyle (most visible in clothing habits), and Darookhanawala is an embodiment of this attitude. Thus, he travels in English style with his cook and manservant and an appetite for biscuits. Wealthy upper-class Indians on the subcontinent had taken to leisure travel quite widely by that time, as is documented splendidly in the study by Pramod Nayar (2017, 2020). In East Africa, however, leisure travel was as yet generally restricted to Europeans and Americans, thus making Darookhanawala a noteworthy exception. His narrative style is that of the "lone traveller" whose companions and servants are simply edited away, resulting in a rhetorical emphasis on the traveller's inner experiences and moral judgements (Walchester 2020, 35). The servants are mentioned only twice during the whole narrative and the reader learns nothing about their names or interests.

An interesting mix of intertextual references becomes visible in Darookhanawala's treatment of the various African ethnic groups. He begins his account ${ }^{9}$ with stories of cannibalism among the Manyema-stories that had circulated since the travels of Henry Morton Stanley several decades earlier. ${ }^{10}$ This beginning provides the travelogue with an aura of adventure and courage so typical of Victorian travel writing. He aligns these so-called cannibals with evil black demons mentioned in books familiar to him, such as the Arabian Nights, the Shah Namah and the Guru Granth Sahib of the Sikhs (Darookhanawala [1905] 1997, 179). He continues by stating that "our Zoroastrian religion tells us to destroy demons. [...] Our Iranian tales about heroes fighting such demons fill us with awe [...]" (Darookhanawala [1905] 1997, 179). And

$9 \quad$ Salvadori re-arranged Darookhanawala's text during the editing process but provides a table of contents of the original arrangement (see below). The linearity I argue with here is based on the original arrangement. Salvadori $(1997,104)$ notes that the Manyema, who live in Eastern Congo, were regarded as cannibals by all Europeans at the time. They had suffered heavily during raids by slave hunters. Manyema slaves were well-known on the plantations of Zanzibar. The fight against cannibalism was given as a major legitimation for European rule in the colonies. 
he concludes the tale of the Manyema-as-cannibal demons in typically pro-Empire fashion with the words: "The cannibals have not been just destroyed but they have also been brought to civilization, and this has stopped thousands of lives from being destroyed, and for this the blessing of God goes to our Empress Queen, there is no doubt about that" (Darookhanawala [1905] 1997, 179-80).

He contrasts this tale directly with that of the "naked Kavirondo" (today's Luo) whose lack of clothing is remarked upon by almost all travellers, whether European or East African, who pass through their territory (including Adamji and Ham Mukasa). For these people Darookhanawala chooses a different narrative frame, namely that of the 'noble savage'. Ever since Rousseau's enlightenment argument of native Americans as 'better humans' in contrast to the decadence of European civilisation, the trope of 'noble savages' became a self-critical, but none the less heavily paternalistic style of describing colonised peoples. The encounter between narrator and observed persons does not happen on an equal footing. Darookhanawala writes:

Of all the naked tribes who live in this area, the ones with the most integrity are the naked Kavirondo. [..] If we compare their integrity with that of sophisticated people, then the so-called cultured modern generation should be ashamed of themselves. They call themselves cultured and clothed in fashionable clothes but I consider them naked under their so-called respectability. These Kavirondo people go about naked but lead simple honest lives according to the Zoroastrian principles of Good Thoughts, Good Words and Good Deeds (lit. Humata, Hukta and Huvarashta). These people are the only ones who live according to the precepts of Good Thinking, Good Speaking, Good Doing (lit. Manashni, Gavashni and Kunashni). [...] The Kavirondo do not know about telling lies and being deceitful. They are truthful, honest and God-fearing and although they appear naked to the eyes, they are worthy of great respect. [...] They lead the happiest of existences on this earth. (Darookhanawala [1905] 1997, 132-34)

Darookhanawala transposes the idea of natural religion so prominent among enlightened philosophers and idealist travellers into the language of his Parsi worldview resting on the most well-known principles of Zoroastrianism. He closes the passage with the stylistically necessary moment of self-criticism:

Many naked men and women passed by where I could see them and to my eyes they seemed strange. [...] When I was preaching about not going naked I felt that I was doing a very noble thing but [...] one of the elderly men started shaking with rage. He told me that I was a very wicked man to have only seen the nakedness of sex. He said that God had created them naked and they remained naked to please God. [...] It was because I was full of lust I covered myself. When the interpreter told me all this I became pale with shock and shame. (Darookhanawala [1905] 1997, 133)

With these thoughts, Darookhanawala follows a typical pattern of reflexive travel writing in which the traveller-author strives for experiences of spiritual growth. He presents himself as a person who is willing and capable of learning from the 'noble savages'. This critical self-reflexiveness is not repeated later in the text where he provides standard paternalistic ethnographic descriptions of the various peoples he passes during his train journey, again 
typical of any European travel account of the time (Darookhanawala [1905] 1997, 157-61). The intertextual entanglements and cosmopolitan habitus of Darookhanawala come to be expressed through his Zoroastrian adaptation of Victorian tropes of supremacy. The narrative style of the lone traveller which suppresses subordinate voices and the normative patterns of comparison are the same while being framed in the scriptural stories and religious codes of the Persianate world.

\section{Entanglements of Editorial Co-Travelling}

All travelogues under discussion here are currently only available as texts edited by people other than the authors. The various processes of selection, translation and commenting provide valuable insights into a century of interpretating these texts authored by East Africans. Early interpretations are framed by the same cosmopolitan and imperial world order that structured the authors' own perception on their respective journeys. Later interpretations are informed either by postcolonial perspectives on East African literature or by historical interest in the information provided in the texts, among the latter of which I place my own analysis presented here. In the following I sketch out a century of editorial forewords and analyse the further entanglements of the published texts in colonial and postcolonial history of East Africa. Not only did the authors chart their own place in the mobile cosmopolitan atmosphere they themselves moved in, but their editors equally emplaced their texts in a variety of discourses on colonialism and postcolonialism.

The travelogues of Amur bin Nasur, Silimu bin Abakari and Ham Mukasa narrating their voyages to Europe were probably read as inverse ethnographies at the time. Ham Mukasa's struggles to describe elevators, underground trains, the mob of London or the noise of a factory belt certainly provoked amusement among British readers for their naiveté, just as German readers must have laughed over Amur bin Nasur's attempts at describing circus shows and museums. A mild critique civilatrice of European morals might also have been in the minds of Büttner, Velten and Millar, although the published works contain little criticism of white people. The editors explicitly removed critical passages from the original narratives, with Ernest Millar, for example, travel companion of Apolo Kagwa and Ham Mukasa, stating that he had softened certain passages "unsavoury" to European readers (Millar [1904] 1998, 39). Benevolent paternalism and genuine interest in the views of the 'educated native' best describe the motivations for collecting, translating and publishing the Kiswahili and Luganda texts. The editorial process, however, reduced the narrators' own voices and any genuine critique they might have had. ${ }^{11}$

Taban lo Liyong and Simon Gikandi, two eminent scholars of English language postcolonial literature, edited, commented and re-published the travel journal of Ham Mukasa-precisely with a view to restoring these voices to a larger contemporary readership. Though both editors did not have access to the Luganda manuscript, and thus could not produce new translations,

11 For those readers with a more satirical penchant, the philosophical and literary genre of the lèttres persanes might have come to mind. The Swahili accounts written by Amur bin Nasur and Silimu could well have inspired the narrative framework of Hans Paasche's (1921) biting critique of German imperialism, prewar militarism and consumerism formulated as Die Forschungsreise des Negers Lukanga Mukara ins innerste Deutschlands (Expedition of the Negro Lukanga Mukara into Inner Germany). Paasche, formerly a military and naval officer stationed in German East Africa during the Maji-Maji War, returned home to become a leading figure in the Lebensreform movement. As Velten had published his books on Swahili customs and linguistics just a couple of years previously for exactly this colonial clientele, it can well be surmised that Paasche was familiar with the Swahili travelogues. 
they reconstructed the context of Apolo Kagwa's and Ham Mukasa's journey to Britain in their respective introductions. It is in this space that Millar's influence is countered by reminding the readers of the Ugandan politicians' plans for a utopian postcolonial future. The 1975 edition of the travels of Ham Mukasa and Apolo Kagwa was edited and abridged by Taban lo Liyong, who styles the two royal leaders as unequivocal heroes of their time. Reversing Millar's editorial policy of removing unpalatable remarks made by Ham Mukasa about Europeans, lo Liyong states that he removed any excessive praise of the Europeans (1975, vi). Simon Gikandi re-published the version of Ernest Millar with a new introduction and some new comments. He discusses the literary style in more detail and thus is able to deconstruct the seeming obsequiousness of the text on a more structural level. Neither editor, however, discusses the missionary Christian framing of the narrative and its function in the critique of British civilization-a topic I will turn to below.

Ham Mukasa's travelogue was not the only one in this collection to be re-published several times. In 1965, Lyndon Harries translated an abridged selection from Velten's collected volumes on travel narratives and on the customs of the Swahili into English (Velten 1901a, 1901b; Velten and Mwenyi Bakari 1903a, 1903b). His bilingual publication in a Tanzanian publishing house was expressly aimed at a local readership. And indeed, the English version of Chande's account was closely followed by Abdulrazak Gurnah in his postcolonial novel of 1994 entitled Paradise. The novel reconstructs a local Swahili-Muslim perspective on precolonial and colonial life, based not least on Chande's description of the time. This includes an almost word-for-word narration of the ancestral sacrifice on an island in Lake Tanganyika I discussed earlier (Gurnah 1994, 146-48; Mustafa 2015).

Silimu's account of Russia and Siberia is the most exotic in Velten's collection, which is certainly why it has attracted particular attention and has been translated, sometimes from the Swahili original and sometimes from Harries' slightly abridged English version, into Italian, Russian and French over the course of several decades. Silimu's employer Theodor Bumiller accompanied his friend Herrman von Wissmann on several hunting trips in East Africa (as recorded by Wissmann ${ }^{12}$, but not by Silimu), but also on a trip to the Altai Mountains which was made possible by the recent extension of the Trans-Siberian Railway, a few years ahead of the Uganda Railway. Typically for the leisure hunter, Wissmann dedicates many pages in his (unpublished) account of the trip to the Altai mountains to the types of game they are hunting, their habitat, and the victorious kills of the hunters (Perbandt 1907). Silimu is well acquainted with big game hunting in East Africa alongside his master and does not question the motives for such a journey. But not being acquainted with the Siberian fauna he struggles to find Kiswahili names for the animals, referring to bears as "European lions," deer as "gazelles" (swala), and to the Argali mountain sheep as "sheep with horns as big as a buffalo" (Abakari 1901b, 269). In his rendering of the Siberian experiences, Silimu closely follows his German masters' derogatory perspective on Russian culture and absolutist rule by the Czar. The Russians thus appear mostly as dirty, sluggish, uncivilised people, smoking and drinking too heavily and dirtying the railway compartments. In the remote borderland between the Russian Empire and China, Silimu's party meets a nomadic, shamanic people Silimu calls the Kalmyks $^{13}$, for whom he shows some ethnographic interest. While again reproducing stan-

12 Wissmann's account of this journey was never published, but is quoted at great length in a rather hagiographic biography compiled shortly after his death (Perbandt 1907).

13 At the time of Silimu's account, the nomadic, shamanic Altai people were variously referred to "Kalmyks" or "Mountain Kalmyks." Wissmann refers to the work of the German linguist and specialist in Turk languages, Wilhelm Radloff, and speculates whether these "Mountain Kalmyks" might be Telengit people (Perbandt 
dard German derogatory characteristics ("dirty," "smelly," "lazy," etc.), he compares their nomadic lifestyle favourably with rituals and economies in Tanganyika. For him, the Kalmyks are a Siberian version of the Maasai who live a similarly nomadic life herding their livestock (1901b, 268). He describes their religion as the worship of spirits through rituals performed on specific mountaintops, with horse hides as central material objects in the rituals. He does not describe any specifically shamanic rites of trance or healing, as Wissmann does in his account of the same trip (Perbandt 1907, 476-77), though one might speculate whether such rites are implied because the term Silimu employs for "spirits" is the same as that used in certain ecstatic rituals in East Africa, "shetani."

Interestingly, the changing attitudes of anthropologists towards 'traditional religion' become apparent with each new generation of translators rendering anew this specific passage on the shetani of the Kalmyks: "When those Kalmyks saw me, they bowed down to me [hunisujudia], they had never seen a black man before. They venerate devils [wanaabudu shetani]; they thought I was indeed their devil who had come down from the mountains" [Abakari (1901c), 269, my translation). This term is derived from Arabic shayțān, Satan. In the Swahili context it is employed for spirit beings related to the Quranic jinns, but the exact meaning is not fixed: sometimes, shetani is the umbrella term for all spirit beings and interchangeable with the term pepo, for others it is a distinct category from jinns or pepo ${ }^{14}$. In Swahili culture, as in Cormorian culture, Silimu's culture of origin, spirit possession and mediumship were common features of everyday religious practice cutting across the boundaries of Islam and local traditions (Lambek 1993). Arab terminology and stories from the Quran and the Arabian Nights were amalgamated in local concepts of spirits. Though the spirits were feared for their power to harm humans, they were (and are) a distinct category of beings created by God (the other categories being humans and angels) who are capable of redemption. They are not demons or devils in the Christian sense. So, when Silimu employs this term to describe Kalmyk shamanic religion, he certainly sees strong parallels to folk religion at home.

However, the etymology of the term reverberates well with common European terminology at the turn of the twentieth century, which referred to almost all traditional religion as 'devil worship'. Velten translates "shetani" as "devils" (Teufel) as a matter of course. Silimu and Velten thus used the same word etymologically, but not semantically. In later translations, the terminology shifts together with anthropological awareness of religious and cultural biases. Lyndon Harries (1965, 272) and Rossana Platone (1991, 154) soften their translations of shetani to "evil spirits" or "spiriti maligni," avoiding the loaded terminology of "devil worship." The most recent translation of the text into French by Nathalie Carré (2014, position 4686) chooses to render the term simply as "spirits" ("esprits") with no further valuation. With this shift in terminology, however slight it might seem, the translators' appreciation of Silimu's perspective on the Kalmyks shifts tremendously. In Velten's version of the text, he appears to mimic imperial and Christian disdain for traditional religion and shamanism in particular. In Carré's version he stands out as a more independent and properly Swahili ethnographer in his own right.

The heaviest redaction of a text was undertaken by Cynthia Salvadori. In her introduction to the travelogue of Darookhanawala she points out that the published text in Gujarati did

1907, 476-77), an ethnonym still in use today for this particular branch of the Altaians. However, these so-called "Kalmyks" must not be confused with the Mongol Buddhist Kalmyks in Russia, who live in the autonomous republic of Kalmykia on the edge of the Caspian Sea.

14 Silimu's contemporary, Mtoro bin Mwinyi Bakari, for example, prefers the term pepo to designate the spirits of his homeland. This term is translated by Velten as "evil spirits" (böse Geister). 
not follow any linear plot. It seemed to her and her fellow translators (Vimla Chavda and Shariffa Keshavjee) that the manuscript must have been mixed up in the printing process (Salvadori 1997, 106). I would argue that this re-arrangement is implicitly motivated by two concerns: one of style and structure, and one of political correctness in the modern anthropological sense. Spatio-temporal linearity is a normal feature not only of Victorian, but also of Arab and Persian travel accounts, which certainly makes Darookhanawala's textual structure anomalous. The first part of his narrative features Lake Victoria (his final destination and turning point), while the second half describes his initial motives for travelling and the first leg of his journey. But there might be reasons for that - other than mishaps at the printer's - that Salvadori does not even begin to reflect on. For example, it is apparent that positive features of the land, the people and the journey are given first, while all the annoyances and setbacks of travel are placed at the end. Also, the more adventuresome sub-narratives and the more classical, typically Victorian intertextual passages relating to history, geography and ethnography are given first, while Darookhanawala's more personal reflections on Parsi culture, travel expenses, or organisational tricks for travelling first class follow after and no longer adhere to the neat style of the first part.

It seems to me that Salvadori's second implicit motivation for shifting the contents around might be her strong reluctance to start an account such as this one with a tale of man-eating demons and naked, but noble, Zoroastrian savages (discussed above). By re-ordering the narrative according to principles of temporal and spatial linearity, Salvadori can 'hide' politically incorrect talk of so-called cannibals at the end of the text. By placing the Kavirondo in their correct geographical space, she again reduces the blatant racism of the author's views on African civilisation (or lack thereof) by spatial separation from the tale of the Manyema. Darookhanawala's emphatic self-portrayal as a somewhat puny, humorous, adventuresome and self-reflexive traveller, however, is also hidden away in Salvadori's English version.

In this section I discussed editorial and linguistic aspects of publishing travelogues written by East African authors. Forewords, introductions and comments emplace the original texts for Western and East African readerships within a cosmopolitan world. While colonial commentators tended to exoticize the texts, postcolonial editors stress, with various political emphasis, the importance of reading testimonies from the colonial period in order to better understand the independence of thought and the experiential freedom of contemporary protagonists.

\section{Shifting Centres and Peripheries: Religious Reframing of the Imperial World Order}

Travellers in foreign countries are by necessity challenged to reflect on religious and social complexity more intensely than would be normal at home (Nolde 2006). In their introduction to a collected volume on cosmopolitanism as a historical perspective, Löhr and Gißibl (2017) coin the term "cosmobilities" to shed light on the importance of a variety of mobile practices within cosmopolitan milieus, linked in particular to their subversive potential. They argue that openness towards mobility as a matter of principle enables people to perceive sociocultural diversity and thus to question established political hierarchies, and to reflect on and narratively reframe the boundaries of their social belonging (Löhr and Gißibl 2017, 32). In the following discussion I analyse the potential of this approach by teasing out several ways through which the East African travellers reframe and subvert the dominant political order 
by taking their own respective religious networks as additional or, more often than not, as an alternative point of identity.

Mobility and reflexivity come together when traversing 'storied places' where geographical locations are linked to well-known myths or legends. One cannot pass such a 'storied place' without invoking connected narratives and reflecting on their meaning. This is exactly how Ham Mukasa and Silimu bin Abakari recount their passage through the Red Sea. Both Biblical and Quranic stories are referenced by the authors while describing the passage from Aden to the Mediterranean. Both authors describe the ship, the engines, the port labourers and flying tradespeople, the Arab houses and the extreme heat in fairly similar terms, but they order the geographical places according to their own religious cosmology. Ham Mukasa equates the Red Sea with the flight of Jesus from Herod. While continuing on through the Mediterranean, he then lists a number of places where St. Paul the Apostle had travelled and preached the message of Christ (Mukasa [1904] 1998, 70-71). Silimu, however, mixes the story of the flight of Jesus and that of Moses fleeing from the Egyptians (Abakari 1901c, 120-21). The plot is that of Moses dividing the sea in order to let his people pass through safely while the pursuing soldiers of the Pharaoh were drowned. Strangely, Silimu gives the name of the prophet Isa (Jesus) as the protagonist of this story. It might be supposed that the story of Moses was familiar to him as it is prominent in the Quran, but that it was interposed in his mind with the New Testament story recounted by the Europeans he was travelling with and which was probably new to him. Certainly not part of the European narrative of the Red Sea is Silimu's detailed reference to two large and beneficent Muslim pilgrimages which take place annually in the port city of Aden dedicated to the saint (wali) Eidarusi and to Sheikh Othman (Abakari 1901c, 119-20).

Silimu is truly thrilled whenever he meets fellow Muslims in the most unexpected places, especially on the journey through Russia. It is through his Sunni Muslim identity, indeed, that he can build on networks of fellowship that undercut Christian society. Neither his German master nor the Russian imperial officials in Siberia have any impact on his perspective. He is deeply impressed by the presence of Muslims even in the most remote areas of the world as he had known it, such as Kirgiz Muslims on the border between Siberia and China:

When our translators told us that they had Islam I didn't believe them. I said: 'There is no Islam here. How should it come to such a faraway place?' The translators told me: 'Ask them for their Islamic name.' I ventured: 'Salaam 'aleikum.' They answered 'aleikum salaam.' Now they were very much amazed that I had Islam. (Abakari 1901b, 270)

The margins of the imperial world order from Silimu's East African perspective begin to form a new centre (Diebold 2021). He subsequently learns more about their life and notes differences in the ritual laws observed by fellow Sunni Muslims such as the Tatars in Moscow and the Kirgiz. He mentions, for example, the Tatars' strange habit of eating horseflesh, which would be frowned upon in Zanzibar (Abakari 1901b, 261), or the Kirgiz' laxity in drinking fermented mare's milk, which would be subsumed under forbidden intoxicating beverages at home (Abakari 1901b, 270-71). Nonetheless, he describes the nomadic Kirgiz and the city dwellers alike as people of great learning belonging to either the Hanafi or the Hanbali law schools (Abakari 1901b, 279). He approves that the shops close down during prayer time. The admiration expressed by Kirgiz Muslims for his own Quranic learning makes him appreciate his own religious identity all the more. While Wissmann only sees Muslim antipathy towards 
Christians, comparable to that in North Africa and the Near East (Perbandt 1907, 496), Silimu feels a sense of brotherhood in the ancient Muslim cities, formerly at the centre of the Persian Muslim world, now on the periphery of the Russian Empire and very far away from his native Comoro Islands.

Mary Louise Pratt (1992) describes the narrative positioning of travellers such as David Livingstone and Richard Burton, who describe their explorations in East Africa at great length, as that of "monarchs of all I survey." Taking up this label, Tabish Khair argues that

in this sense, travel and travel writing were (and are) about the gaze of power. It is this that helps explain how the movements of some (non-European) peoples were effectively frozen under that narrative gaze, even when European travelers noted the presence of non-European travelers in the margins of their texts. (Khair 2006, 7)

East African travellers might be monarchs in actual fact (or at least the regent of Buganda, as Apolo Kagwa was), but their narrative gaze is not imperialistic, though it might be chauvinistic or racist in places. Instead, their narrative strategy is one of finding a middle space in the complex social and racial hierarchies of East Africa. Sharing the same geographical space in East Africa, but not the same space of communication, the divide between Europeans, South Asians and Africans is reinforced in all the travel narratives under scrutiny here. Passing by Baku, Silimu, for example, briefly mentions Zoroastrianism, which he labels as a "religion [dini] of fire" (Abakari 1901b, 279). But though he mentions India as the current home of the Parsis, he does not make any explicit connection to Zanzibar and the Parsi community there.

At the same time, the Zanzibari Parsi Darookhanawala repeatedly castigates lower caste Indians in East Africa for their filthiness and general ill behaviour, ${ }^{15}$ blaming them for the British exclusion of all Indians from higher administrative posts and land tenure, including all higher caste Indians such as himself:

"So before complaining about the English mistreatment of the Indians it is very important that this kind of [unclean] behaviour be changed. ... I don't blame the English and I feel the Indians are entirely to be blamed because of their lack of manners. Wherever I've been I have noticed this. Memons, Bhatias, Khojas and Banias are all alike in their unclean manners. Nobody who appreciates neatness and cleanliness can bear this." (Darookhanawala [1905] 1997, 166 and passim)

He argues that well-behaved Indian locals—or even black noblemen—should be given more responsibility in the colonial administration. Citing the Protectorate of Uganda as an example, Darookhanawala laments the incompetence of "narrow-minded, old-fashioned officials" of the British government who "want to improve the area [for farming] for the Europeans only" ([1905] 1997, 149). He is very critical of racial segregation following the South African example and pleads for self-rule for the natives, whether black or Indian, within the superstructure of the British Empire: "The officials [...] should not treat the Europeans differently and the natives, just because they are black, insultingly, for to do so is insulting God who created them equal" ([1905] 1997, 149). According to Desai (2013, 98), the Gujarati title of his book Andarama Rahelo Africa should best be translated as "In Darkness Remains Africa"

15 Darookhanawala's tirade against filthy behaviour in railway compartments is highly reminiscent of Silimu's disgust at the uncleanliness of Russians travelling by train-a trope that continues in travelogues even to this day! 
(rather than Africa in Darkness as suggested by Salvadori). Desai argues that that this phrase exactly captures Darookhanawala's perception of the ineptitude of colonial administration as long as Indian middle-men are not included in the British project of modernity $(2013,98)$.

A Christian reframing of the imperial world order is achieved by Ham Mukasa with a more subtle narrative strategy. Establishing a Christian identity is achieved by Ham Mukasa in three ways. First, the kings of Uganda had a long history of changing alliances with coastal Muslim and Christian European forces. Apolo Kagwa and Ham Mukasa had trained in Christian schools from an early age and represented the final banishment of Muslim politics at the court, though many Muslim converts still lived in the country (Kahyana 2018). Crossing Lake Victoria for the first time, Apolo Kagwa and Ham Mukasa are curious to learn about the way of doing things on the Kenyan shore, though they are appalled and astounded at the dirt and simplicity of the people. The nakedness of the Luo revolts them. Apolo Kagwa finds it difficult to understand how Bugandan women from his kingdom could have moved there with their Swahili husbands; and even less how they could have converted to the Islamic religion of the coastal traders (Mukasa [1904] 1998, 52). This passage in the narrative is only a few sentences long, but it clearly conveys the disdain expressed for the Muslim Swahili and the traditionalist Luo in Kenya, which in both cases reflects a tendency to mirror British racial prejudices, as well as anti-Muslim sentiment at the Buganda court.

Second, Christianity serves as a framework for the Bugandan travellers and has a strong influence on their itinerary, though it is never reflected on in these terms. As the coronation of King Edward VII had to be postponed due to his ill-health, Apolo Kagwa and Ham Mukasa were taken by their host Ernest Millar on a tour of the country, visiting a number of cities between London and Glasgow. The factories, printing presses and schools they were taken to were all situated in cities with family members or friends of missionaries in Uganda. Ham Mukasa is shown a representative cross-section of British industry and culture, but always on the basis of the personal networks of individual missionary agents: "After a short rest, we left for Birmingham, the city in which Miss Dallison, the nurse of Mengo hospital, was born. [...] The next morning, July $3^{\text {rd }}$, we went to see the factories of Birmingham" (Mukasa [1904] 1998, 111).

Third, Christianity provides a framework for evaluating human nature. Ham Mukasa offers a fine example of the complex layering of observation and corresponding evaluation of simple actions in the face of imperial racism and Christian humanity. He describes a scene on deck while their ship is passing through the Red Sea during which Ernest Millar renders a simple service to Apolo Kagwa, prime minister (Luganda: katikiro) and regent of the Kingdom of Buganda:

Mr. Millar helped us a great deal in everything we required, and would not sit with the other Europeans [on the ship], but always sat with us, and covered the Katikiro with his own rug when they sat together, so as to keep his knees warm, though other Europeans would not do such a thing as that and he was not afraid of their despising him. I think there were two reasons why he did this: first, because he was a real Christian; and secondly, he followed the customs of his nation in their kind government, and did not want to bring shame on this nation, because the English rule righteously in all lands, whether of wise nations or of ignorant nations, and they honour men who do not themselves expect to be honoured. This nation is a truly peaceable nation in all its laws, which are in many ways like the laws in the Bible. (Mukasa [1904] 1998, 68) 
Ugandan postcolonial critique of Ham Mukasa rests on passages such as this in which he blatantly overstates the praise of British rule in Buganda (Kahyana 2018, 38). But reading this quote more closely, it becomes evident that Christian ethics and Biblical law take precedence over national law. It is the Biblical framework against which ethical practices are measured, be they carried out by individuals or by nations. It is also the Christian framework that places Ham Mukasa and the Katikiro on the same level of humanity as the British missionary Ernest Millar, despite the manifestly racist and repressive social reality the travellers experience during their journey to Europe. As Johannes Fabian (2014) has famously argued, coevalness is denied to colonized or so-called 'primitive' populations in anthropological texts whenever they are rendered as people without history, or as people standing outside of time. Ham Mukasa's reference to Christianity (or Silimu's reference to Islam and Darookhanawala's to Zoroastrianism), however, emplaces him as a protagonist of a so-called historical religion, and thus gives him access to 'history' and coevalness. Apolo Kagwa's and Ham Mukasa's other books on Bugandan history and on aspects of theology reinforce this plea for coevalness at a time when this structural imbalance of representation was neither recognized nor up for discussion.

The hyperbolic style of the passage quoted above with its strong contrast between the social reality of racism and the perfect laws of human kindness in Christianity should be read as a subtle admonition to all British readers to reflect more on the ostensible contradiction between their actual deeds and their propagated moral standards in the colonial context. The rhetorical contrast of the Katikiro's humbleness with the publicly demonstrative help provided by Millar turns a simple act of rug-sharing into a political statement on the colonial world order. This interpretation of the scene is reinforced through the contrast with the rug-sharing story of Ebrahimji Adamji discussed above. For Ebrahimji, accepting the rug was a sign of desperation, help rendered and help accepted. But being in the socially higher position, he certainly did not want to overcome the caste distinction in a more general way. Ham Mukasa's insistent praise of their travel companion Millar and his friends and family, however, reinforces the impression that coevalness is being denied them again and again during their travels. It is Christianity (and Ham Mukasa's own open-hearted humanity) that provides a moral—and a rhetorical—framework outside social reality capable of creating equality between colonial masters and subjects.

\section{Conclusion}

In the East African travelogues under analysis here processes of intertextual appropriation and narrative inversions of imperial, racial and missionary topoi are central to the re-affirmation of religious identities. I presented three central themes arising from a comparative analysis of the texts. The first analytical thread followed two commercial travellers, both Swahili Sunni and South Asian Shi'i (Bohra), who are familiar with the inland routes of caravans and the newly opened railway. Mounting either their own trade expeditions or managing caravans for European explorers, these authors frame their diary-style narratives in terms of authority, political prowess, deceit and subterfuge. While these narratives focus quite strongly on financial accounting, they do also include continuous references to private insights into networks of communal support on the road divided according to religious, caste and ethnic affiliations. The second line of analysis focussed on narrative passages of a more observational style scattered throughout most travelogues, and central to the work of three authors. Descriptions 
of foreign curiosities, eccentricities and horrors encountered along the way can be entertaining, educational and morally instructive. Though intertextual references to European ethnographies can be traced in all texts, the authors reframe, and occasionally even invert, the Western Christian perspective by consistently comparing the Other-whether positively or negatively-to rituals, customs and religious ethics of their own home community. In the hierarchical setting of East Africa, these narratives of observation allow the authors to emplace themselves intellectually and morally in relation to their religious and ethnic competitors. The third analytical strain picked up on narratives of leisure travel and tourism as particular loci of excessive paternalism and exoticism expressed through affectively loaded accounts of technological and educational advances in the colonial empire. The author's self-characterisation as an independent and heroic figure in Victorian travelogues structurally covers up the agency of the travellees. I discussed an East African Parsi tourist as a case in point who reconfigures genre typical tropes of 'black cannibals' and 'noble savages' into Parsi cosmology following narrative conventions already established on the Indian subcontinent, while praising Indian engineering on the newly opened Uganda-Kenya railway.

In the next part, my analysis shifted from narrative structure to the social conditions restricting the publication of written travelogues by East African authors and impinging also on translations made decades later. The narratives in their currently available form have at least two layers of motivation for producing them, and two potential readerships: those the traveller-author might have had in mind, and those followed by the editors. The narrative voices cannot be taken as 'authentic' because it is impossible to reconstruct the environments in which some of the texts were actually formulated and which passages were later omitted during translation and editing for publication. Some of the texts were re-issued multiple times so that layerings of external motivation can be observed through the editorial forewords over the space of more than a century.

Following the final thread of my analysis, I argued how the published texts reflect in a deeply significant way the entanglements of the imperial world order, the plurality of languages and religions, and the difficulties of navigating racial separations. Drawing on the concept of cosmobility, I argued that the authors and their editors use the narratives in a potentially subversive way to comment on imperial and racial hierarchies following both geographic and moral itineraries from the East African religious centres to European peripheries.

Travelogues are vehicles for discussing appropriation, positioning and preservation of dignity when away from home. Disdain, disgust and snobbishness, sometimes in a paternalistic style, feature in the narratives just as much as admiration, appreciation and thankfulness. On the road, travellers are dependent on guides, translators and hosts. Moments of powerlessness, as well as moments of triumph and heroism, are not only humorous, but more importantly characterise the degree of independent agency the author perceives for himself. Age, gender and socio-economic position define the perspective of the narrator just as much as the ease (or discomfort) of travelling. Religious values, however, cut through these boundaries inasmuch as they offer succour in moments of homesickness, but also frame the narratives themselves. The complexity of societies in distant parts, which are only partially understood (if at all), is rendered comprehensible through references to a world ordered by the narrator's God.

I opened my study with a quote by Silimu. Let me close with him, too. Whenever he has leisure time for himself during his journey through Russia and Siberia as the personal servant of a German doctor, he enjoys observing local customs, visits town centres, speaks to learned men in the local mosques and stands in awe of Islamic civilisation in Bukhara and Samarkand. 
He closes his account by praising God and Bumiller for allowing him to see so much of the world. Being a rich man, he says, is not sufficient for such travels; rather "it takes a man with a good spirit [roho njema] and faith [imani]" (Abakari 1901b, 280). Only in hindsight does he realise how big a place the world is and how much he learnt, things that he would never even have heard of at home (Abakari 1901b, 280). With this reference to seeking and finding knowledge of the world (even as far away as the Chinese border), Silimu justifies travel in accordance with the conventions of travelogues of all times and places, but obliquely also with a well-known tradition of the Prophet Muhammed: "Seek knowledge even if you have to travel as far as China."

Narrative agency, or the power of narrative in fashioning identity and biography, is thus a most intriguing feature that travelogues embody and should be studied further in order to better understand the dynamics of religious contact zones. The East African travelogues discussed in this article have no theological bent; they seldomly reflect explicitly on religious values. Yet, descriptions of everyday events repeatedly contain references to religion. The wonder of meeting fellow Muslims in Moscow or the frustration at being unable to perform certain Bohra holiday requirements are emotions that structure the narrative identity of the travellers. These references are seldom explained, as prior knowledge of the specific concerns is expected among the readers. It is precisely the ease and assurance of such references that stabilise the narrative religious identity of the authors in their texts.

\section{References}

Abakari, Selim [Silimu] bin. 1901a. "Safari Yangu Ya Nyassa Waqati Bwana Major Von Wissmann Alipopeleka Stima Katika Juto La Nyassa." In Safari Za Wasuaheli, edited by Carl Velten, 50-105. Göttingen: Vandenhock \& Ruprecht.

— 1901b. "Safari Yangu Ya Russia Na Ya Sibirien." In Safari Za Wasuaheli, edited by Carl Velten, 253-82. Göttingen: Vandenhoeck \& Ruprecht.

_ 1901c. "Safari Yangu Ya Ulaya Toka Daressalama Haț̣a Berlin." In Safari Za Wasuaheli, 106-25. Göttingen: Vandenhoeck \& Ruprecht.

- 2015. Fragments Retrouvés. Moroni: Bilk \& Soul.

Adamji, Ebrahimji Noorbhai. (1905) 1997. "My Journeys to the Interior. Accounts of Five Journeys from Mombasa to the Interior 1902-1905." In Two Indian Travellers. East Africa 1902-1905. Being Accounts of Journeys Made by Ebrahimji N. Adamji, a Very Young Bohra Merchant from Mombasa, and Sorabji M. Darookhanawala, a Middle-Aged Parsi Engineer from Zanzibar, edited by Cynthia Salvadori, with the assistance of Judy Aldrick, 13-74. Mombasa: Friends of Fort Jesus.

Alam, Muzaffar, and Sanjay Subrahmanyam. 2007. Indo-Persian Travels in the Age of Discoveries, 1400-1800. Cambridge [etc.]: Cambridge University Press.

Alpers, Edward A. 1975. Ivory and Slaves. Changing Pattern of International Trade in East Central Africa to the Later Nineteenth Century. Berkeley and Los Angeles: University of California Press.

Bakari, Mtoro bin Mwenyi. 1901a. "Khabari Ya Nchi Ya Wazaramu Na Dasturi Za Wazarum Kama Zilizotungwa Na Mtoro Bin Mwenyi Bakari." In Safari Za Wasuaheli, edited by Carl Velten, 205-52. Göttingen: Vandenhoeck \& Ruprecht.

_ 1901b. "Safari Ya Udoe Hațta Uzigua Na Khabari Za Wadoe Na Mila Yao Inatoka Kwa Mtoro Bin Mwenyi Bakari." In Safari Za Wasuaheli, edited by Carl Velten, 126-80. 
Behrend, Heike. 1998. “'Wondering with an Unending Wonder': Remarks on Ham Mukasa's Journey to England in 1902." History in Africa 25: 55-68.

Büttner, Karl Gotthilf. 1894. Anthologie Der Suaheli-Litteratur. Gedichte Und Geschichten Der Suaheli. Zwei Theile in Einem Bande. Berlin: Felber.

Carré, Nathalie. 2014. De la Côte aux confins: Récits de voyageurs swahili. Kindle. Paris: CNRS.

Clifford, James. 1997. Routes: Travel and Translation in the Late Twentieth Century. Cambridge, Massachusetts, London, England: Harvard University Press.

Darookhanawala, Sorabji Manekji. (1905) 1997. "Africa in Darkness." In Two Indian Travellers. East Africa 1902-1905. Being Accounts of Journeys Made by Ebrahimji N. Adamji, a Very Young Bohra Merchant from Mombasa, and Sorabji M. Darookhanawala, a Middle-Aged Parsi Engineer from Zanzibar, edited by Cynthia Salvadori, with the assistance of Judy Aldrick, 111-81. Mombasa: Friends of Fort Jesus.

Desai, Gaurav Gajanan. 2013. Commerce with the Universe: Africa, India, and the Afrasian Imagination. New York: Columbia University Press.

Diebold, Jan. 2021. "Alternative Weltläufigkeit und die agency des 'Dieners' Silimu bin Abakari." In Imperiale Weltläufigkeit und ihre Inszenierungen: Theodor Bumiller, Mannheim und der deutsche Kolonialismus um 1900, edited by Bernhard Gißibl and Katharina Niederau, 145-70. Vandenhock \& Ruprecht.

Fabian, Johannes. 2014. Time and the Other: How Anthropology Makes Its Object. New York: Columbia University Press.

Forsdick, Charles, Kathryn Walchester, and Zoë Kinsley, eds. 2019. Keywords for Travel Writing Studies: A Critical Glossary. London: Anthem.

Geider, Thomas. 1992. "Early Swahili Travelogues." In Sokomoko. Popular Culture in East Africa, edited by Werner Graebner, 27-65. Amsterdam / Atlanta, GA: Rodopi.

Green, Nile. 2012. "Africa in Indian Ink: Urdu Articulations of Indian Settlements in East Africa." The Journal of African History 53 (2): 131-50.

—, ed. 2014. Writing Travel in Central Asian History. Bloomington: Indiana University Press.

Gurnah, Abdulrazak. 1994. Paradise. London: Hamish Hamilton.

Harries, Lyndon. 1965. Swahili Prose Texts: A Selection of the Material Collected by Carl Velten from 1893 to 1896. London / Nairobi: Oxford University Press.

Idrissi Alami, Ahmed. 2013. Mutual Othering: Islam, Modernity, and the Politics of Cross-Cultural Encounters in Pre-Colonial Moroccan and European Travel Writing. Albany: State University of New York Press.

Johannsen, Dirk, and Anja Kirsch. 2020. "Narrative Cultures and the Aesthetics of Religion: An Introduction." In Narrative Cultures and the Aesthetics of Religion, edited by Dirk Johannsen, Anja Kirsch, and Jens Kreinath, 1-13. Leiden: Brill.

Kahyana, Danson Sylvester. 2018. "Shifting Marginalities in Ham Mukasa and Sir Apolo Kagwa's Uganda's Katikiro in England.” Journal of African Cultural Studies 30 (1): 36-48. https://doi.org/10.1080/13696815.2016.1246244.

Khair, Tabish. 2006. "African and Asian Travel Texts in the Light of Europe. An Introduction." In Other Routes: 1500 Years of African and Asian Travel Writing, edited by Tabish Khair, Martin Leer, Justin D. Edwards, and Hanna Ziadeh. Oxford: Signal Books.

Khair, Tabish, and Amitav Ghosh, eds. 2006. Other Routes: 1500 Years of African and Asian Travel Writing. Oxford: Signal Books. 
Kinsley, Zoë. 2019. "Picturesque." In Keywords for Travel Writing Studies: A Critical Glossary, edited by Charles Forsdick, Kathryn Walchester, and Zoë Kinsley, 184-86. London: Anthem.

Kirk-Greene, Anthony H. M., and Paul Newman. 1971. West African Travels and Adventures: Two Autobiographical Narratives from Northern Nigeria. New Haven: Yale University Press.

Lambek, Michael. 1993. Knowledge and Practice in Mayotte. Local Discourses of Islam, Sorcery, and Spirit Possession. Toronto: University of Toronto Press.

Lo Liyong, Taban. 1975. "Introduction." In Sir Apolo Kagwa Discovers Britain, edited by Ham Mukasa, Taban Lo Liyong, and v-xvi, v-xvi. African Writers Series. London: Heinemann.

Löhr, Isabella, and Bernhard Gißibl. 2017. "Die Geschichtswissenschaften vor der kosmopolitischen Herausforderung." In Bessere Welten: Kosmopolitismus in den Geschichtswissenschaften, edited by Bernhard Gißibl and Isabella Löhr, 9-43. Frankfurt / New York: Campus.

Mackenthun, Gesa, Andrea Nicolas, and Stephanie Wodianka, eds. 2017. Travel, Agency, and the Circulation of Knowledge (Cultural Encounters and the Discourses of Scholarship). Vol. 9. Münster / New York: Waxmann.

Mazrui, Alamin. 2017. "The Indian Experience as a Swahili Mirror in Colonial Mombasa." African and Asian Studies 16 (1-2): 167-87. https://doi.org/10.1163/15692108-1234 1376.

Middleton, John. 1992. The World of the Swahili. An African Mercantile Civilization. New Haven and London: Yale University Press.

Millar, Ernest. (1904) 1998. "Preface." In Uganda's Katikiro in England, by Ham Mukasa, edited by Simon Gikandi, 39-40. Manchester: Manchester University Press.

Mukasa, Ham. (1904) 1998. Uganda's Katikiro in England. Manchester: Manchester University Press. With Notes and an Introduction by Simon Gikandi.

Mustafa, Fawzia. 2015. "Swahili Histories and Texts in Abdulrazak Gurnah's Paradise." English Studies in Africa 58 (1): 14-29.

Naithani, Sadhana. 2010. The Story-Time of the British Empire: Colonial and Postcolonial Folkloristics. Jackson: University Press of Mississippi.

Nasur, Amur bin. 1894. "Hekaya Ilmezkur Abd Rasul Allahi Amur Bin Nasur IlOmeiri. Bijedihi (Leben Des Herrn Amur)." In Anthologie Der Suaheli-Litteratur. Gedichte Und Geschichten Der Suaheli. Zwei Theile in Einem Bande. Erster Theil, edited by Karl G. Büttner, 146-75. Berlin: Felber.

Nayar, Pramod K. 2020. Indian Travel Writing in the Age of Empire: 1830-1940. New Delhi: Bloomsbury India.

Nayar, Promod K., ed. 2017. Indian Travel Writing 1830-1947. Vol. V: Africa, Afghanistan and the Middle-East. Abingdon / New York / Tokyo: Routledge / Edition Synapse.

Newman, Daniel L. 2017. "'Hell for Horses, Paradise for Women'. Power and Identity in Nineteenth-Century North African Narratives of Travel to Europe." Edited by Gesa Mackenthun, Andrea Nicolas, and Stephanie Wodianka. Travel, Agency, and the Circulation of Knowledge 9: 183-99.

Nolde, Dorothea. 2006. "Religion und narrative Identität in Reiseberichten der Frühen Neuzeit." In Historische Diskursanalysen: Genealogie, Theorie, Anwendungen, edited by Franz X. Eder, 271-89. Wiesbaden: VS Verlag für Sozialwissenschaften.

Paasche, Hans. 1921. "Die Forschungsreise Des Afrikaners Lukanga Mukara Ins Innerste Deutschland." Hamburg: Junge Menschen. 
Perbandt, Conradin von. 1907. "Reise Nach Sibirien." In Hermann von Wissmann. Deutschlands Größter Afrikaner, edited by Conradin Perbandt, Georg Richelmann, Rochus Schmidt, W. Steuber, and A. Becker, 467-99. Berlin: Schall.

Pesek, Michael. 2006. "Cued Speeches: The Emergence of Shauri as Colonial Praxis in German East Africa, 1850-1903." History in Africa 33: 395-412.

Pettinger, Alasdair, and Tim Youngs, eds. 2020. The Routledge Research Companion to Travel Writing. Abingdon, Oxon, New York, NY: Routledge.

Platone, Rossana. 1991. "Un Africano Nel Grande Nord." Europa Orientalis 10: 131-66.

Pratt, Mary Louise. 1992. Imperial Eyes: Travel Writing and Transculturation. 2. revised edition. London: Routledge.

Rashid, "Abdallah bin. 1901. "Safari Yangu Ya Afrika Toka Bahari Ya Suaheli Hațta Baḥari Ya Pili Katika Safari Ya Bwana Graf Von Götzen.” In Safari Za Wasuaheli, edited by Carl Velten, 181-204. Göttingen: Vandenhoeck \& Ruprecht.

Salvadori, Cynthia, ed. 1997. Two Indian Travellers. East Africa 1902-1905. Being Accounts of Journeys Made by Ebrahimji N. Adamji, a Very Young Bohra Merchant from Mombasa, and Sorabji M. Darookhanawala, a Middle-Aged Parsi Engineer from Zanzibar. With the assistance of Judy Aldrick. Mombasa: Friends of Fort Jesus.

Salvadori, Cynthia, and Andrew Fedders. 1989. Through Open Doors: A View of Asian Cultures in Kenya. Rev. Nairobi, Kenya: Kenway Publications.

Schön, Jacob Friedrich. 1885. Magána Hausa: Native Literature, or Proverbs, Tales, Fables and Historical Fragments in the Hausa Language. To Which Is Added a Translation in English. London: Society for Promoting Christian Knowledge.

Smethurst, Paul. 2019. “Traveller/Travellee.” In In Keywords for Travel Writing Studies: A Critical Glossary, edited by Charles Forsdick, Kathryn Walchester, and Zoë Kinsley, 268-70. London: Anthem.

Smethurst, Paul, and Julia Kuehn, eds. 2015. New Directions in Travel Writing Studies. Basingstoke, Hampshire, New York: Houndmills.

Tshande, Sleman bin Mwenyi. 1901. "Safari Yangu Ya Barra Afrika." In Safari Za Wasuaheli, edited by Carl Velten, 1-49. Göttingen: Vandenhoeck \& Ruprecht.

Uganda Railway. 1911. The Uganda Railway, British East Africa, from Mombasa to Lake Victoria Nyanza. London: Waterlow \& Sons. https://babel.hathitrust.org/cgi/pt?id=mdp.3901 $5027226185 \&$ view $=1$ up\&seq $=3$.

Velten, Carl, ed. 1901a. Safari Za Wasuaheli. Göttingen: Vandenhoeck \& Ruprecht.

- ed. 1901b. Schilderungen Der Suaheli: Von Expeditionen v. Wissmanns, Dr. Bumillers, Graf v. Götzens, und Anderer. Göttingen: Vandenhoeck \& Ruprecht.

Velten, Carl, and Mtoro Mwenyi Bakari. 1903a. Desturi Za Wasuaheli Na Khabari Za Desturi Za Sheri‘a Za Wasuaheli. Göttingen: Vandenhoeck \& Ruprecht.

—. 1903b. Sitten und Gebräuche der Suaheli: Nebst einem Anhang über Rechtsgebräuche der Suaheli. Göttingen: Vandenhoeck \& Ruprecht.

Walchester, Kathryn. 2020. Traveling Servants: Mobility and Employment in British Fiction and Travel Writing 1750-1850. Routledge Research in Travel Writing. New York: Routledge.

Wimmelbücker, Ludger. 2008. Mtoro Bin Mwinyi Bakari: Swahili Lecturer and Author in Germany. Dar es Salaam: Mkuki na Nyota.

Youngs, Tim. 2013. The Cambridge Introduction to Travel Writing. Cambridge: Cambridge University Press. 